\title{
Activation of the Salicylic Acid Signaling Pathway Enhances Clover yellow vein virus Virulence in Susceptible Pea Cultivars
}

\author{
Go Atsumi, Uiko Kagaya, Hiroaki Kitazawa, Kenji Suto Nakahara, and Ichiro Uyeda \\ Pathogen-Plant Interactions Group, Graduate School of Agriculture, Hokkaido University, Sapporo 060-8589, Japan
}

Submitted 14 April 2008. Accepted 8 October 2008.

\begin{abstract}
The wild-type strain (Cl-WT) of Clover yellow vein virus (CIYVV) systemically induces cell death in pea cv. Plant introduction (PI) 118501 but not in PI 226564. A single incompletely dominant gene, Cyn1, controls systemic cell death in PI 118501. Here, we show that activation of the salicylic acid (SA) signaling pathway enhances CIYVV virulence in susceptible pea cultivars. The kinetics of virus accumulation was not significantly different between PI 118501 (Cyn1) and PI 226564 (cyn1); however, the SAresponsive chitinase gene $(\mathrm{SA}-\mathrm{CHI})$ and the hypersensitive response (HR)-related gene homologous to tobacco HSR203J were induced only in PI 118501 (Cyn1). Two mutant viruses with mutations in P1/HCPro, which is an RNA-silencing suppressor, reduced the ability to induce cell death and $S A$ CHI expression. The application of $\mathrm{SA}$ and of its analog benzo $(1,2,3)$ thiadiazole-7-carbothioic acid $S$-methyl ester (BTH) partially complemented the reduced virulence of mutant viruses. These results suggest that high activation of the SA signaling pathway is required for CIYVV virulence. Interestingly, BTH could enhance Cl-WT symptoms in PI 226564 (cyn1). However, it could not enhance symptoms induced by White clover mosaic virus and Bean yellow mosaic virus. Our report suggests that the SA signaling pathway has opposing functions in compatible interactions, depending on the virus-host combination.
\end{abstract}

Additional keywords: resistance gene.

A simple and cost-effective way of controlling plant virus disease is the use of resistant cultivars. Many researchers have studied the resistance mechanisms that confine viruses to primary infected tissue. One of the most studied examples is that mediated by a direct or indirect interaction between a resistance $(R)$ gene product and the product of a pathogen avirulence $(A v r)$ gene. This results in the hypersensitive response (HR) in which the pathogen is arrested in and around the site of primary infection. The HR is often accompanied by host cell death. The HR is associated with changes in ion fluxes, the generation of reactive oxygen species and nitric oxide, the activation of mitogen-activated protein kinase cascades, the alteration of phytohormone balance, dynamic transcriptional change, and the induction of pathogenesis-related (PR) genes

Corresponding author: Ichiro Uyeda; Telephone: +81 11706 2473; Fax: +81 11706 2483; E-mail: uyeda@res.agr.hokudai.ac.jp

* The $e$-Xtra logo stands for "electronic extra" and indicates that seven supplemental figures are published online.
(Soosaar et al. 2005). Salicylic acid (SA) plays a critical signaling role in the activation of disease resistance. Arabidopsis thaliana mutants that are disrupted in SA biosynthesis and signaling pathways enhance susceptibility to pathogen infection (e.g., eds 1, pad4, sid2, and eds5 mutants) (Durrant and Dong 2004). However, SA appears to have prodeath and antideath functions in HR-expressing tissues (Alvarez 2000).

Although there are some instances in which no resistancebreaking (virulent) virus emerged, many resistances can be overcome by virulent strains (Lecoq et al. 2004). Thus, it is very important to investigate events at the molecular level to understand how disease is expressed after infection; however, this area is poorly understood (Whitham et al. 2006). As observed in incompatible interactions, compatible viruses can also induce the SA signaling pathway in an SA-dependent manner in A. thaliana (Huang et al. 2005; Love et al. 2005). In contrast, plants that are compromised in SA accumulation such as $\operatorname{sid} 2$ and $N a h G$ mutants do not show enhanced susceptibility (Huang et al. 2005; Love et al. 2005). However, many reports have indicated that the exogenous application of SA inhibits virus multiplication (virus replication and cell-to-cell and long-distance movement), resulting in symptom attenuation (Singh et al. 2004). This implies that SA can induce a state of resistance against viruses but is not effective in compatible virus infections. In tobacco and $A$. thaliana, SA-induced resistance against Tobacco mosaic virus (TMV) is altered in plants that are treated with salicylhydroxamic acid (SHAM, an inhibitor of mitochondrial alternative oxidase $[\mathrm{AOX}]$ ) or in transgenic plants that have altered levels of Aox, suggesting that AOX plays a role in antiviral defense (Chivasa et al. 1997; Gilliland et al. 2003). Furthermore, an RNA-dependent RNA polymerase is suggested to participate in SA-induced antiviral defense (Gilliland et al. 2003; Xie et al. 2001). However, the mechanisms of SA-induced antiviral defense may be different among host species, even for the same virus (Mayers et al. 2005).

Several lines of evidence indicate that plants use the RNAsilencing system as an antiviral defense in compatible interactions (Ding and Voinnet 2007). To counteract antiviral RNA silencing, many viruses have an RNA-silencing suppressor (RSS) (e.g., Potyvirus-encoded P1/HCPro and Cucumovirusencoded 2b) (Anandalakshmi et al. 1998; Brigneti et al. 1998; Kasschau and Carrington 1998). Zhang and associates (2006) demonstrated that Cucumber mosaic virus (CMV) 2b inhibits argonaute (AGO1) slicer activity in A. thaliana, suggesting that, because the $A$. thaliana agol mutant showed higher susceptibility to CMV, RSS activity has an important role in viral virulence (Morel et al. 2002).

Clover yellow vein virus (ClYVV), a member of the genus Potyvirus, causes severe damage to important legume crops, 
A
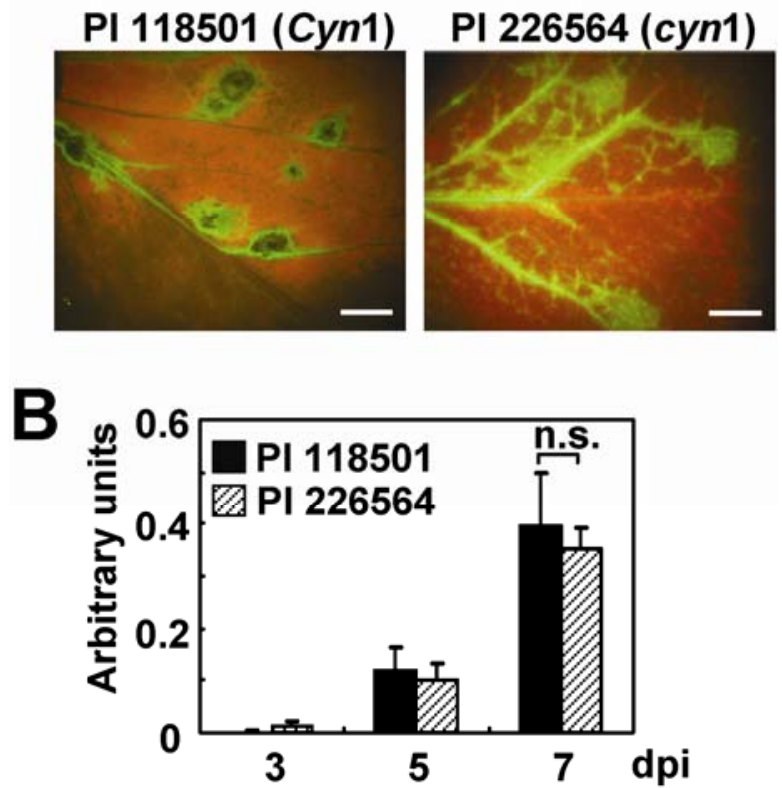

Fig. 1. Accumulation of Clover yellow vein virus (ClYVV) in inoculated leaves of plant introduction (PI) 118501 (Cyn1) and PI 226564 (cyn1). ClYVV tagged with green fluorescent protein (GFP) was mechanically inoculated on leaves of pea PI 118501 (Cyn1) and PI 226564 (cyn1). Systemically induced cell death was detected in the former but not in the latter. A, Photographs were taken under UV light 7 days post inoculation (dpi). Cell death was observed in the center of GFP foci in PI 118501(Cyn1) but not in PI 226564 (cyn 1$)$. Scale bar $=0.25 \mathrm{~cm}$. B, GFP foci were excised at the indicated time points, and the relative amount of virus was measured by double-antibody sandwich enzyme-linked immunosorbent assay using antibodies against ClYVV coat protein. Virus accumulations were normalized to the signal intensity of the positive control (ClYVV-infected tissue). The error bars indicate standard deviation of means for four replicates. A $t$ test was applied to the data at $7 \mathrm{dpi}$; n.s. = not significant. including pea and broad bean (Ravelo et al. 2007; Yambao et al. 2008). In pea, ClYVV systemically induces cell death, a process that is controlled by a single incompletely dominant gene, Cyn 1 , and ultimately results in plant death (Ravelo et al. 2007). ClYVV infectious cDNA was synthesized and developed as a vector in legumes (Masuta et al. 2000; Takahashi et al. 1997; Wang et al. 2003). Point mutations in P1/HCPro of ClYVV attenuate symptom development in broad bean and compromise the RSS activity of P1/HCPro mutants (Yambao et al. 2008).

We focused on the role or roles of the SA signaling pathway in viral virulence using the pea-ClYVV system (Ravelo et al. 2007). We show that the SA signaling and HR-related pathways are activated in plant introduction (PI) 118501 (Cyn1) infected with ClYVV and are accompanied by cell death. CIYVV mutants that compromised the RSS activity of P1/HCPro reduced the virulence because they reduced the activation of the SA signaling pathway. The mutants can partially recover virulence with the application of benzo $(1,2,3)$ thiadiazole-7-carbothioic acid $S$-methyl ester (BTH) and SA. We also show that BTH can enhance symptom expression such as vein clearing and mosaic and induce cell death with severe yellowing in PI 226564 (cyn1) infected with ClYVV but not with White clover mosaic virus or Bean yellow mosaic virus.

\section{RESULTS}

Virus accumulation did not differ significantly

between PI 118501 (Cyn1) and PI 226564 (cyn1).

Previous results showed that CIYVV induced cell death systemically in pea PI 118501 (Cyn1) but not in PI 226564 (cyn1) (Ravelo et al. 2007). We used a green fluorescent protein (GFP)-tagged virus to readily monitor virus infection (Fig. 1A). The symptoms induced in PI 118501 and PI 226564 by GFP-tagged ClYVV (Cl-WT) were identical to those induced by the original ClYVV no. 30 strain (Ravelo et al. 2007). PI 118501 induced cell death along the vein on inoculated leaves
A

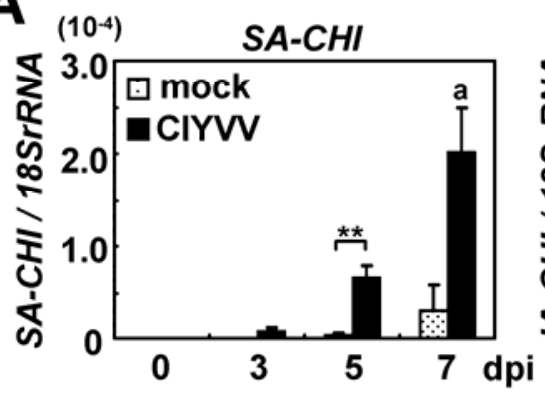

B

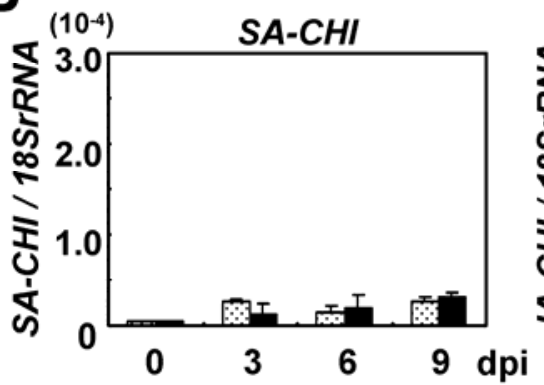

$\left(10^{-4}\right)$

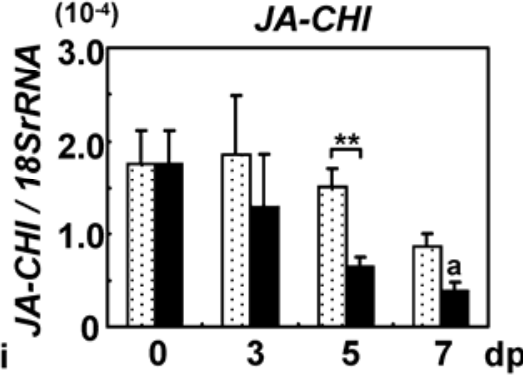

$\left(10^{-4}\right)$

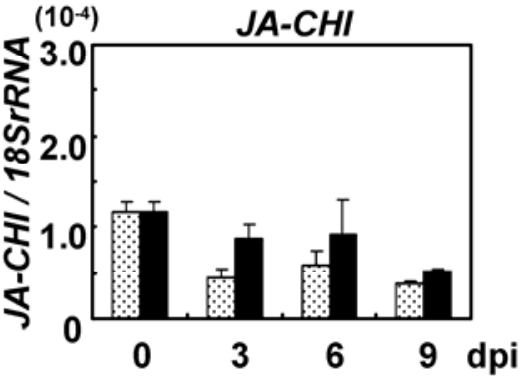

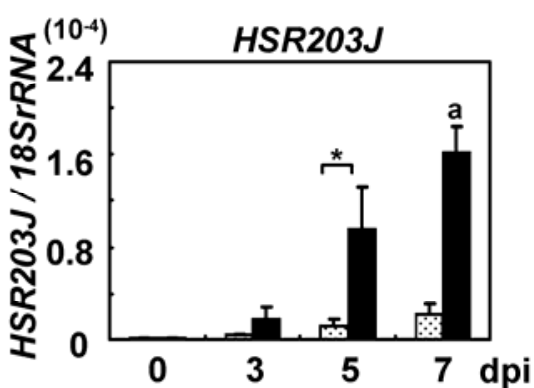

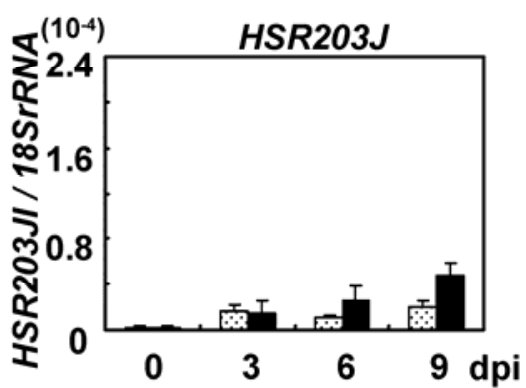

Fig. 2. Expression of salicylic acid (SA)-responsive chitinase (SA-CHI), jasmonic acid (JA)-responsive chitinase (JA-CHI), and HSR203J in plant introduction (PI) 118501(Cyn1) and PI 226564 (cyn1) infected with wild-type Clover yellow vein virus (ClYVV). Time course of SA-CHI, JA-CHI, and HSR203J expression. Total RNA was isolated from inoculated leaves of A. PI 118501 at 0, 3, 5, and 7 days post inoculation (dpi) or B, PI 226564 at 0, 3, 6, and 9 dpi and used for real-time polymerase chain reaction. All mRNA expression data were normalized to $18 S$ rRNA. Error bars indicate standard deviation of the means for three replicates. A $t$ test was applied to each dataset at 5 dpi. Symbols: $*$ and $* *$ indicate $P<0.05$ and 0.01 , respectively; a $=$ cell death induction was observed macroscopically. Experiments were repeated at least three times. 
5 to 6 days post inoculation (dpi), and cell death was induced in stems and upper uninoculated leaves, resulting in plant death within 2 weeks (Ravelo et al. 2007). PI 226564 showed weak symptoms (yellowing approximately 2 weeks after inoculation) on inoculated leaves and vein clearing and mosaic symptoms on systemically infected leaves (Ravelo et al. 2007). GFP fluorescence derived from Cl-WT, with cell death in the center of infected foci in PI 118501(Cyn1) but not in PI 226564 (cyn 1$)$ is shown in Figure 1A. To examine whether high virus accumulation was a cause of the cell death phenotype, we excised infection foci from inoculated leaves at 3, 5, and 7 dpi and measured the amount of virus by double-antibody sandwich enzyme-linked immunosorbent assay (DAS-ELISA) (Fig. 1B). There was no detectable significant difference between PI 118501 and PI 226564 at any time point.

\section{CIYVV-activated SA signaling and HR-related pathways in PI 118501 (Cyn1).}

Using synteny studies, Ravelo and associates (2007) reported that Cyn 1 mapped in the pea chromosome region corresponding to a resistance gene analog (RGA) gene cluster in Medicago truncatula, a model legume (Aubert et al. 2006; Zhu et al. 2002). If ClYVV-induced systemic cell death (SCD) is initiated from $\mathrm{R}$ protein recognition, it is possible that the SA signaling and HR-related pathways are activated. To examine this, we compared the expression patterns of two PR genes (i.e., the SA- and jasmonic acid (JA)-responsive chitinase genes) and the HR-related gene homologous to tobacco HSR203J (re- ferred to as $S A-C H I, J A-C H I$, and $H S R 203 J$, respectively) between PI 118501 (Cyn1) and PI 226564 (cyn1) (Chang et al. 1995; Ichinose et al. 2001; Nakamura et al. 2003; Pontier et al. 1994). We conducted expression analysis in inoculated leaves because synchronous virus long-distance movement was difficult to control. Total RNA was extracted from leaves inoculated with Cl-WT and the expression level was analyzed by realtime polymerase chain reaction (PCR) (Fig. 2). In PI 118501, $S A-C H I$ was significantly induced at $5 \mathrm{dpi}$, whereas $J A-C H I$ was downregulated (Fig. 2A). Similarly, HSR203J expression was increased significantly at 5 dpi in PI 118501 (Fig. 2A). The transcript levels of $S A-C H I, J A-C H I$, and HSR203J were not significantly upregulated in PI 226564 (cyn1) (Fig. 2B).

\section{A reduced ability to induce cell death was accompanied by reduced virus accumulation in PI 118501 (Cyn1).}

Yambao and associates (2008) demonstrated that mutations in P1/HCPro reduced the ability to induce SCD in broad bean. To examine whether mutants also reduced the virulence in pea, we inoculated GFP-tagged P1/HCPro mutants in PI 118501 and monitored symptoms and GFP fluorescence. We used ClYVV-CB/GFP (Cl-CB) and ClYVV-D193Y/GFP (Cl-D193Y) mutant strains. $\mathrm{Cl}-\mathrm{CB}$ has two point mutations (i.e., one mutation in P1 and another in HCPro), whereas Cl-D193Y has only one mutation in HCPro (Yambao et al. 2008) (Fig. 3A).

Compared with $\mathrm{Cl}-\mathrm{WT}, \mathrm{Cl}-\mathrm{CB}$ induced cell death along the vein after a delay of 2 to 3 days in inoculated leaves but not in the upper uninoculated leaves (Fig. 3B). Monitoring of $\mathrm{Cl}-\mathrm{CB}$
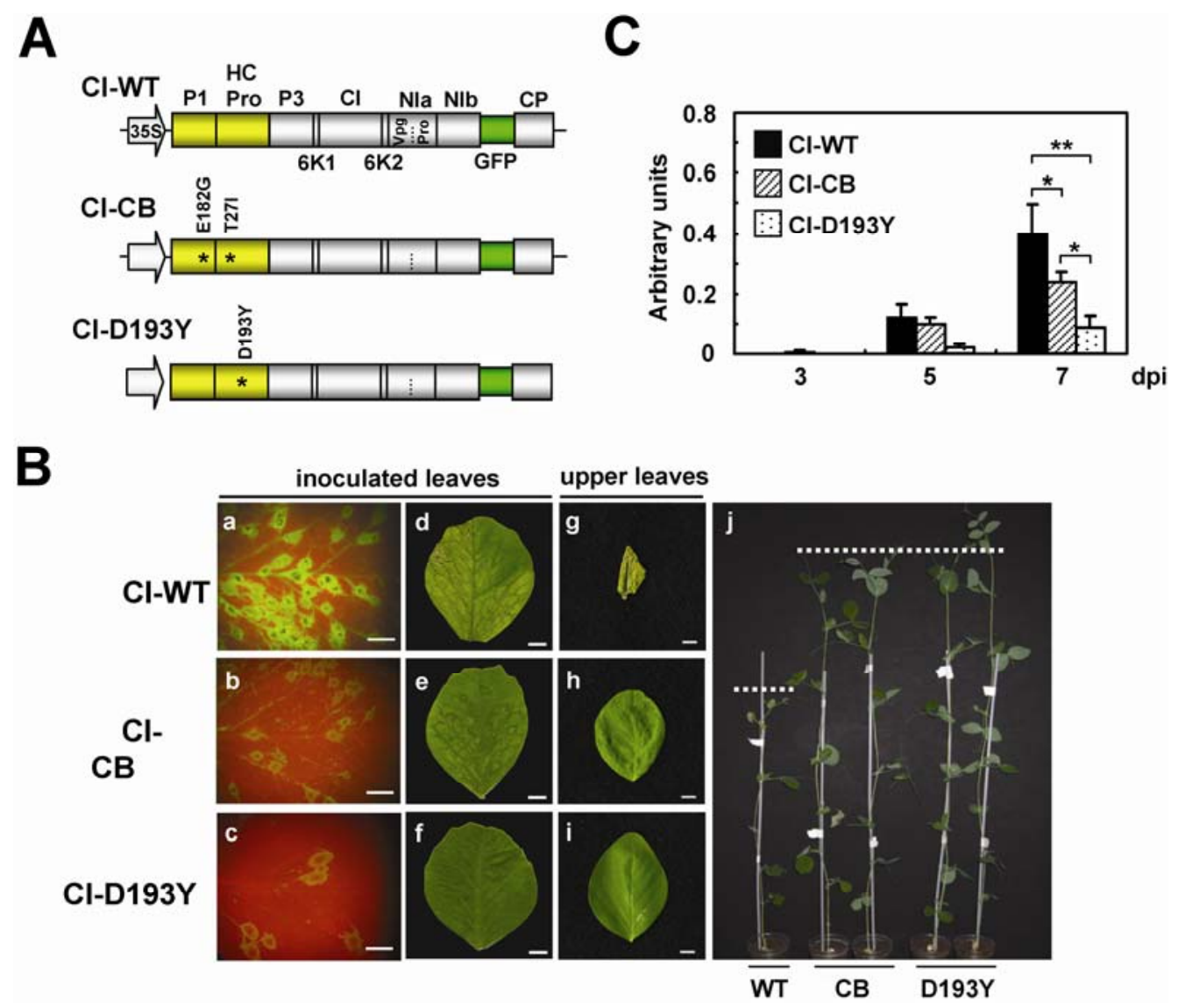

Fig. 3. Symptoms and accumulation of Clover yellow vein virus (ClYVV) P1/HCPro mutants in inoculated leaves of plant introduction (PI) 118501 (Cyn1). A, Schematic representation of infectious cDNA, ClYVV wild type (Cl-WT), and mutants (Cl-CB and Cl-D193Y). Constructs were described previously (Wang et al. 2003; Yambao et al. 2008). B, Viruses were inoculated mechanically. Photographs were taken 5 days post inoculation (dpi) under UV light (a through $\mathrm{c}$ ) and 9 dpi under normal light (d through j) except for $\mathrm{i}$ and $\mathrm{j}$, which were 12 and $11 \mathrm{dpi}$, respectively. Scale bar $=0.25 \mathrm{~cm}(\mathrm{a}$ through $\mathrm{c})$ and $0.5 \mathrm{~cm}$ (d through i). C, The amount of virus was measured by double-antibody sandwich enzyme-linked immunosorbent assay using antibodies against ClYVV coat protein. A Tukey test for a multiple comparison was applied to the data at $7 \mathrm{dpi}$; * and ** indicate $P<0.05$ and 0.01 , respectively. 
by GFP showed no significant difference in virus spread between $\mathrm{Cl}-\mathrm{WT}$ and $\mathrm{Cl}-\mathrm{CB}$. However, GFP fluorescence derived from $\mathrm{Cl}-\mathrm{CB}$ was ring-shaped and less intense (Fig. 3B). ClD193Y did not induce any symptoms in either inoculated or uninoculated leaves, although we could confirm infection by GFP fluorescence and reverse-transcription (RT)-PCR (Fig. 3B; data not shown). As in Cl-CB, the Cl-D193Y-derived GFP signal was ring shaped and less intense than that of $\mathrm{Cl}-\mathrm{CB}$ (Fig. 3B). Because the RSS activity of P1/HCPro-CB and $\mathrm{P} 1 /$ HCPro-D193Y is compromised and the GFP fluorescence derived from mutant viruses was less intense, it is possible that the accumulation of mutant viruses is reduced (Yambao et al. 2008) (Fig. 3B). To compare virus accumulation kinetics, we excised infection foci from inoculated leaves and measured the amount of each virus by DAS-ELISA (Fig. 3C). This showed that $\mathrm{Cl}-\mathrm{WT}$ accumulation was higher than $\mathrm{Cl}-\mathrm{CB}$ at $7 \mathrm{dpi}$, when cell death was observed in Cl-WT infection, but not in Cl-CB. Cl-D193Y accumulation was significantly lower than that of $\mathrm{Cl}-\mathrm{WT}$ and $\mathrm{Cl}-\mathrm{CB}$ at $7 \mathrm{dpi}$.

\section{SA-mediated PR gene expression was delayed or not induced in attenuated mutant infections in PI 118501 (Cyn1).}

To investigate whether mutant viruses are able to activate the SA signaling and HR-related pathways, we performed expression analysis of SA-CHI, JA-CHI, and HSR2O3J using real-time PCR in inoculated leaves (Fig. 4). Cl-CB significantly induced $S A-C H I$ at 12 dpi, indicating that $S A-C H I$ induction was delayed (Fig. 4A). Cl-D193Y did not significantly induce SA-CHI expression at any of the sampled times points (Fig. 4A). However, we could not detect statistically significant activation of HSR203J in Cl-CB and Cl-D193Y infection, although we repeatedly examined the expression levels before and after cell death induction by $\mathrm{Cl}-\mathrm{CB}$ (Fig. 4C).

\section{BTH enhanced cell death}

in attenuated mutant-infected PI 118501 (Cyn1).

Because induction of the SA signaling pathway was reduced in ClYVV mutant-infected plants, we hypothesized that cell death induction requires a highly induced SA signaling pathway. To examine this possibility, Cl-CB- and Cl-D193Y-inoculated plants were treated with BTH and cell death induction was monitored (Fig. 5). BTH activates the SA signaling pathway without the accumulation of SA (Friedrich et al. 1996). In pea, BTH could rapidly and stably induce $S A-C H I$ expression (Supplementary Fig. S1). On leaves inoculated with $\mathrm{Cl}-\mathrm{CB}$, BTH-treated plants showed cell death at $6 \mathrm{dpi}$, which matched the timing for $\mathrm{Cl}-\mathrm{WT}$, whereas control water-treated leaves showed cell death at 8 to 9 dpi (Fig. 5A; data not shown). We also detected cell-death-expressing tissue by trypan blue staining (Fig. 5A). GFP fluorescence showed that cell death was induced in the infection foci (Fig. 5C). Furthermore, BTH could induce cell death on upper uninoculated leaves in $\mathrm{Cl}-\mathrm{CB}$ infection at 9 dpi (Fig. 5A). We confirmed $\mathrm{Cl}-\mathrm{CB}$ infection in the upper leaves of plants treated with BTH or water by GFP fluorescence (data not shown). On leaves inoculated with $\mathrm{Cl}$ D193Y, BTH-treated plants had a few small areas of cell death at $7 \mathrm{dpi}$ but cell death was not induced in water-treated control plants (Fig. 5B). GFP fluorescence indicated that cell-deathexpressing tissue was detectable in the Cl-D193Y-infected area (Fig. 5C).

To further confirm the involvement of the SA signaling pathway in the enhancement of cell death, we applied SA to plants infected with Cl-CB and Cl-D193Y. As a control, we used a biologically inactive isomer of SA, 3-hydroxybenzoic acid (3-HBA). When SA, 3-HBA, and control water were applied to leaves that were inoculated with $\mathrm{Cl}-\mathrm{CB}$ and $\mathrm{Cl}-\mathrm{D} 193 \mathrm{Y}$,
SA did not enhance cell death induction. In contrast, SA induced cell death when applied through the roots by watering plants with the solution. Thus, SA could accelerate cell death induction in leaves that were inoculated with $\mathrm{Cl}-\mathrm{CB}$ and induced cell death in Cl-D193Y (Supplementary Fig. S2). However, the effect of SA was weaker than that of BTH. Cell death was effectively induced in the infection foci in BTH-treated leaves but the extent of cell death was lower in SA-treated leaves (Fig. 5C). To examine the cause of the weak effects of SA, we analyzed the expression kinetics of the SA-inducible chitinase gene after SA and BTH treatment. Total RNA was isolated from the leaves after a one-time application of BTH, SA, and control solutions on the leaves and used for real-time PCR. The results indicated that BTH treatment induced $\mathrm{SA}-\mathrm{CHI} 2$ expression after 1 day and up to 5 days after treatment. However, SA could induce $S A-C H I 21$ day after treatment but not after 2 days. We also examined the responsiveness of $S A-C H I 2$ when plants were watered with SA solution. Although $S A$ $\mathrm{CHI} 2$ was significantly induced at 1 day after treatment, the

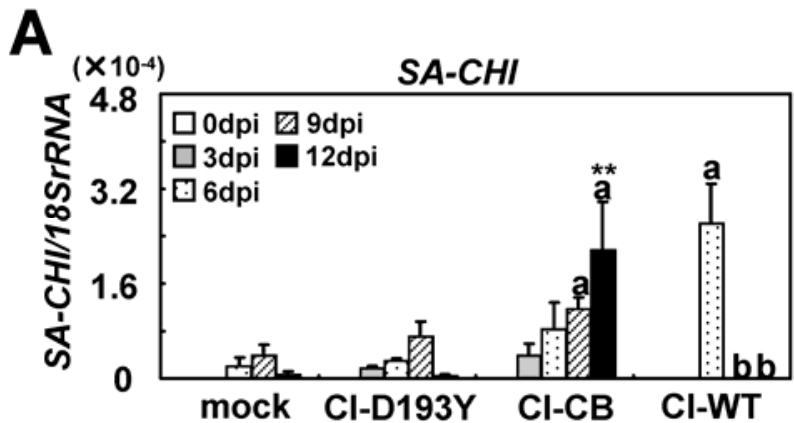

B
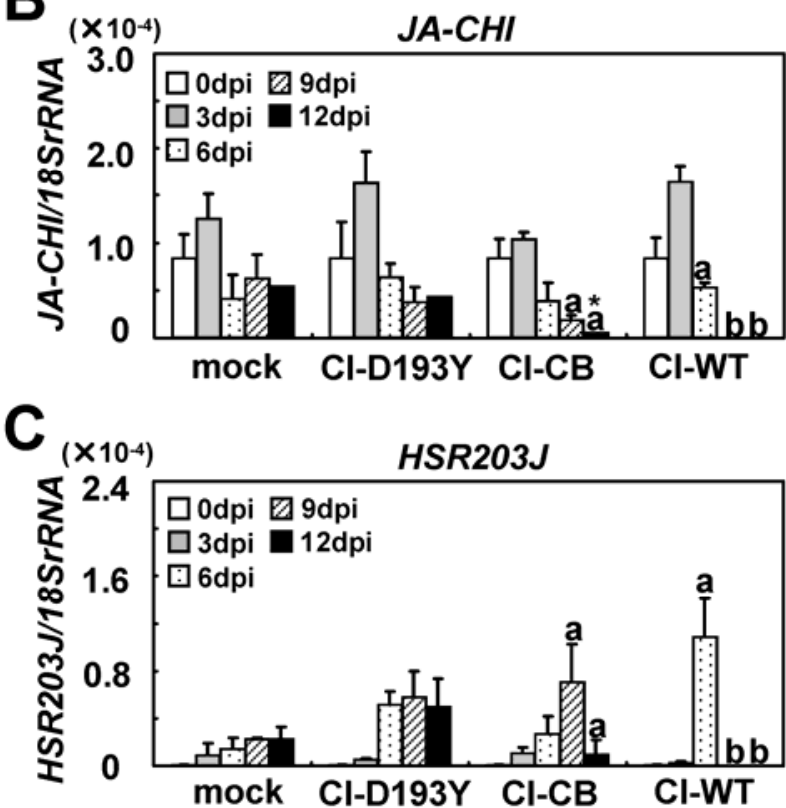

Fig. 4. Expression of salicylic acid (SA)-CHI, jasmonic acid (JA)-CHI, and HSR203J in plant introduction (PI) 118501(Cyn1) infected with Clover yellow vein virus mutants. A, Time course of $S A-C H I$ expression. Total RNA was isolated from inoculated leaves at $0,3,6,9$, and 12 days post inoculation (dpi) and used for real-time polymerase chain reaction. All mRNA expression data were normalized to $18 S$ rRNA. B, Time course of $J A-C H I$ expression. C, Time course of HSR203J expression. Error bars indicate the standard deviation of means for three replicates. Dunnett's test was applied to the data at $12 \mathrm{dpi}$. Symbols: ** and * indicate $P<0.01$ and 0.05 , respectively. Experiments were repeated at least twice; $a=$ cell death induction was observed macroscopically and $b=$ not tested because tissue was completely dead. 
expression level was low at 3 days after treatment. These results suggest that BTH stably activates the SA signaling pathway whereas SA does not, and may explain the different effects in the enhancement of $\mathrm{Cl}-\mathrm{CB}$ and $\mathrm{Cl}-\mathrm{D} 193 \mathrm{Y}$ virulence.

BTH did not affect virus accumulation in inoculated leaves.

Several reports indicate that SA interferes with viral accumulation such as that of TMV and Potato virus $X$ (PVX) in susceptible tobacco plants (Singh et al. 2004). To test whether cell death in BTH-treated leaves was caused by increased accumulation of mutant viruses, we compared the virus accumulation in inoculated leaves (Fig. 6). None of the Cl-WT, Cl-CB, or Cl-D193Y accumulation was affected by BTH application.

BTH also induced cell death in PI 226564 (cyn1).

To further investigate whether SCD induced by CIYVV depends on $C y n 1$ and the upregulation of the SA signaling path- way, BTH was applied to PI 226564 (cyn1) inoculated with Cl-WT and symptoms were monitored (Fig. 7). Surprisingly, BTH-treated plants were severely stunted, and the fifth leaves (third leaf above the inoculated leaf) were dead at $9 \mathrm{dpi}$, in contrast to the water-treated control leaves, which showed vein clearing (Fig. 7A). Leaves that were treated with BTH had severe yellowing and cell death along the veins but control water-treated leaves showed no symptoms or chlorosis (Fig. 7B). BTH-induced cell death was also observed in PI 250438, PI 347457, and PI 331413, which are all non-SCD cultivars (Supplementary Fig. S4) (Ravelo et al. 2007). However, none of these cultivars showed cell death in upper leaves above the cell-death-expressing leaves (recovery phenotype) (Fig. 7A) (Ravelo et al. 2007). We also noted that healthy plants treated with BTH developed smaller upper leaves, but no stunting or cell death was observed (Fig. 8A).

To investigate whether Cl-WT accumulation is affected by BTH application, we compared the virus accumulation in inocu-
A
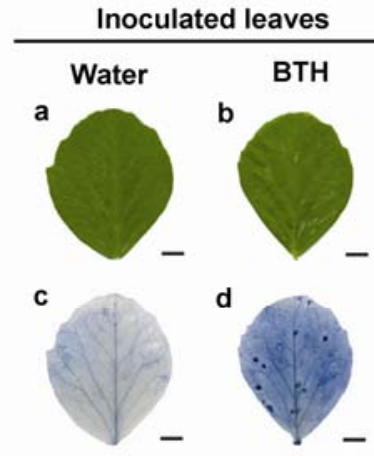
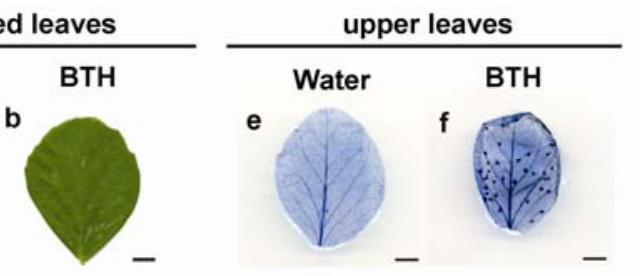

B
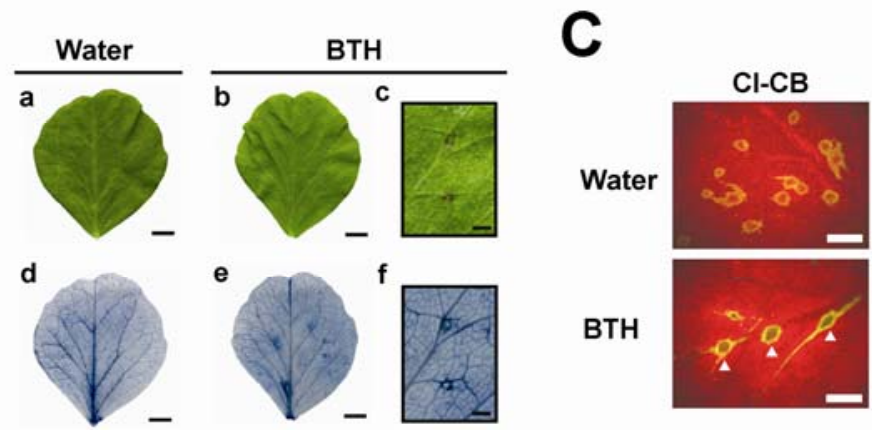

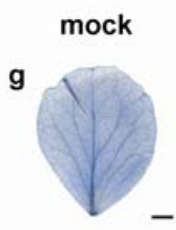

Fig. 5. Application of benzo $(1,2,3)$ thiadiazole-7-carbothioic acid S-methyl ester (BTH) on plant introduction (PI) 118501 (Cyn1) infected with Clover yellow vein virus mutants. BTH was applied to leaves inoculated with Cl-CB and Cl-D193Y. A, Symptoms on inoculated leaves at 6 days post inoculation (dpi) ( $\mathrm{a}$ and $\mathrm{b}$ ). Leaves shown in a and $\mathrm{b}$ were stained with trypan blue to visualize cell-death-expressing tissue (c and d, respectively). Upper uninoculated leaves were stained with trypan blue at $9 \mathrm{dpi}$ (e and f). Mock-inoculated leaves were stained with trypan blue (g). Scale bar $=0.5 \mathrm{~cm}$. B, BTH was applied to leaves inoculated with Cl-D193Y. Symptoms observed on inoculated leaves at $7 \mathrm{dpi}(\mathrm{a}-\mathrm{c})$. Leaves shown in a and b were stained with trypan blue (d and e, respectively). Scale bar $=0.5 \mathrm{~cm}$. Magnified picture derived from $\mathrm{b}$ and e ( $\mathrm{c}$ and $\mathrm{f}$, respectively). Scale bar $=0.1 \mathrm{~cm}$. C, Photographs were taken under UV light at $7 \mathrm{dpi}(\mathrm{Cl}-\mathrm{CB})$ and $8 \mathrm{dpi}(\mathrm{Cl}-\mathrm{D} 193 \mathrm{Y})$. Scale bar $=2 \mathrm{~mm}$.
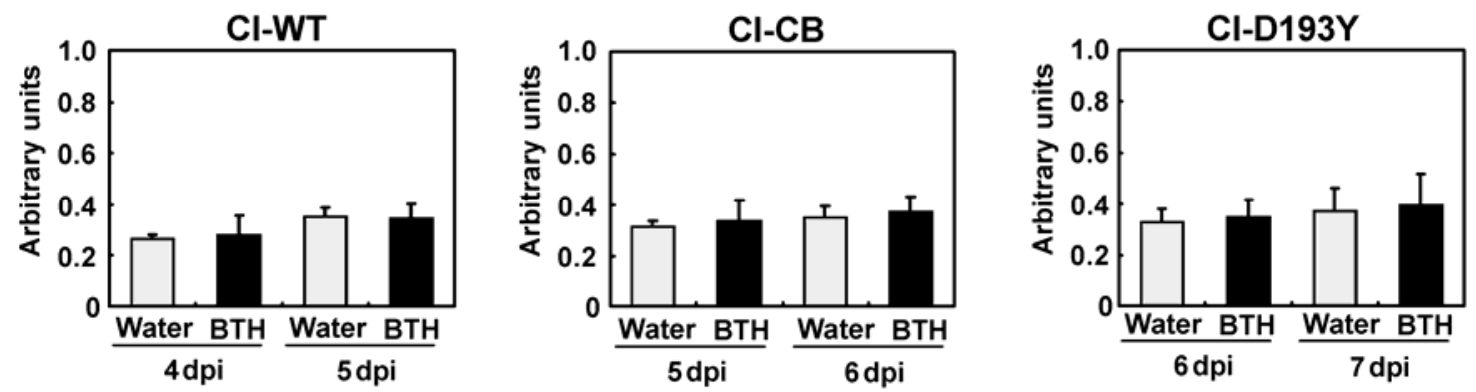

Fig. 6. Effect of benzo $(1,2,3)$ thiadiazole-7-carbothioic acid S-methyl ester (BTH) on the accumulation of Clover yellow vein virus wild type and mutants in plant introduction (PI) 118501 (Cyn1). BTH was applied to leaves that were inoculated with Cl-WT, Cl-CB, and Cl-D193Y. The amount of virus was measured by double-antibody sandwich enzyme-linked immunosorbent assay using antibodies against CIYVV coat protein. 
lated leaves. Comparisons made at 5 and 7 dpi did not show significant differences (Supplementary Fig. S5).

We further tested the effect of exogenous SA application on $\mathrm{Cl}-\mathrm{WT}$-induced symptoms. Plants inoculated with $\mathrm{Cl}-\mathrm{WT}$ were watered with SA, 3-HBA, or control water, but there was no evidence for symptom enhancement by SA (data not shown).

\section{BTH enhanced symptoms in a CIYVV-specific manner} in PI 226564 (cyn1).

In general, the application of BTH (or SA) stimulates the SA-mediated defense pathway and enhances viral resistance in

A

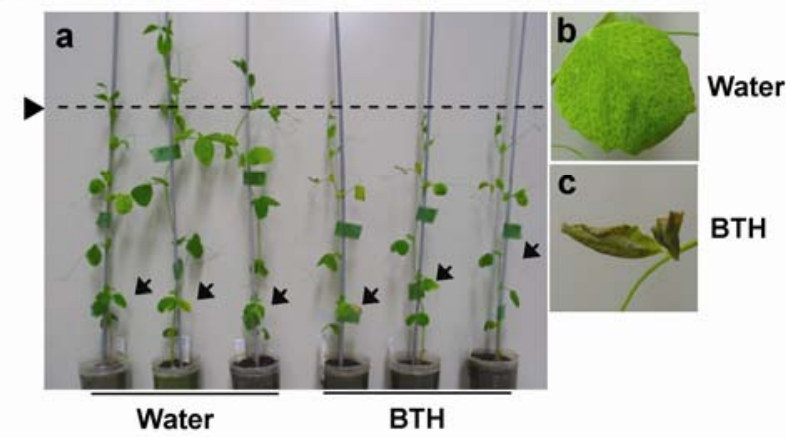

B

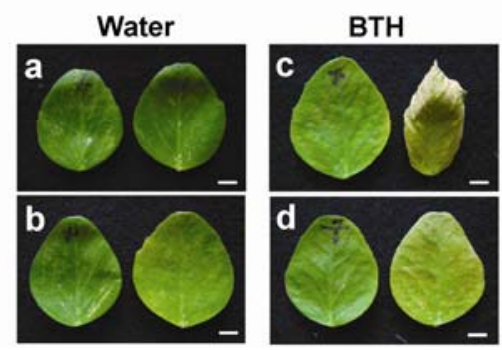

Fig. 7. Application of benzo $(1,2,3)$ thiadiazole-7-carbothioic acid Smethyl ester (BTH) on plant introduction (PI) 226564 (cyn1) infected with Clover yellow vein virus wild type (Cl-WT). BTH was applied to leaves that were inoculated with Cl-WT. A, Symptoms observed in whole plants (a) and upper leaves (b and c) at 9 days post inoculation (dpi). Black arrows indicate the inoculated leaves. B, Symptoms detected on inoculated leaves (17 dpi). Mock-inoculated leaves are shown on the left of each column (ad). Symptoms as shown in a and c were consistently observed; b had the most severe symptoms in water-treated plants and $\mathrm{d}$ had the mildest symptoms in BTH-treated plants. Scale bar $=0.5 \mathrm{~cm}$. All experiments were repeated three times. incompatible interactions (Chandra-Shekara et al. 2004). Similarly, SA treatment inhibits virus multiplication such as replication, cell-to-cell movement, and long-distance transport, resulting in symptom attenuation in compatible interactions (Singh et al. 2004). To investigate whether symptom enhancement by BTH was CIYVV specific in pea, we applied BTH to PI 226564 infected with White clover mosaic virus (WCIMV), a member of the Potexvirus genus. As expected, the application of BTH attenuated symptom development (Fig. 8A). WCIMV induced stunting and cell death in the upper leaves of control water-treated plants; however, no stunting occurred and cell death was slight in the upper leaves of BTH-treated plants.

To examine whether symptom enhancement by BTH occurred in other Potyvirus infections, we applied BTH to PI 226564 infected with Bean yellow mosaic virus (BYMV) CS strain (BYMV CS) or BYMV 90-2 strain (BYMV 90-2) (Fig. 8B). BYMV CS induced vein clearing and mosaic symptoms in control water-treated plants but BTH did not enhance these symptoms (Fig. 8B). The second BYMV strain, BYMV 90-2, induced mild symptoms, chlorosis, and faint mosaic in control water-treated plants but BTH did not enhance these symptoms (Fig. 8B).

We further examined whether BTH can enhance viral symptoms in other host-virus systems. CMV Y strain systemically induced severe yellowing and cell death, whereas PVX UK1 strain induced mild symptoms such as mosaic in Nicotiana benthamiana (data not shown). CMV infection induced $P R I$ expression; however, infection by PVX did so weakly (Supplementary Fig. S6) (Kalde et al. 2007). We applied BTH to $N$. benthamiana infected with CMV and PVX. In CMV infection, BTH-treated plants showed severe cell death symptoms in both inoculated and upper leaves at 13 dpi but control watertreated plants showed yellowing and weak cell death symptoms in both inoculated and upper leaves (Supplementary Fig. S7A). In contrast, BTH did not induce cell death and attenuated symptom development such as stunting in PVX infections.

\section{DISCUSSION}

CIYVV activated the SA signaling and HR cell death pathways in the Cyn 1 line (PI 118501) but not in the cyn 1 line (PI 226564) of pea. Furthermore, mutations in P1/HCPro reduced the ability to induce systemic cell death and SA-mediated PR gene expression, and the application of BTH or SA partially complemented the reduced cell death induction of mutant viruses in PI 118501 (Cyn1). In addition, BTH specifically enhanced CIYVV virulence in PI 226564 (cyn1).
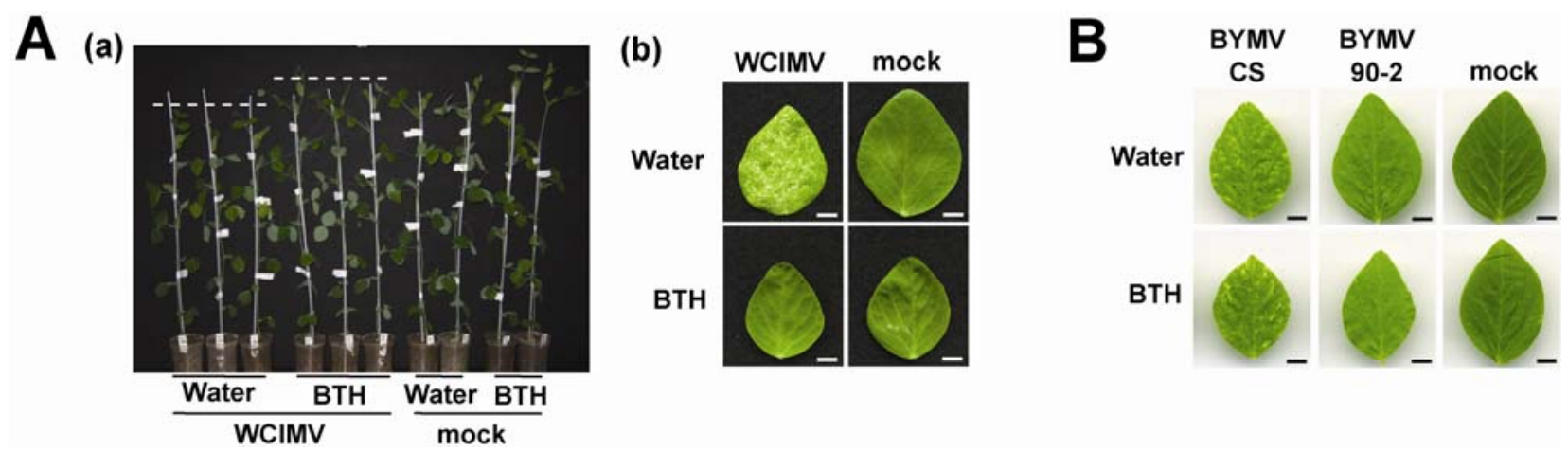

Fig. 8. Application of benzo (1,2,3) thiadiazole-7-carbothioic acid S-methyl ester (BTH) on PI 226564 (cyn1) infected with White clover mosaic virus (WClMV) and Bean yellow mosaic virus (BYMV). BTH was applied to leaves that were inoculated with viruses. A, WClMV-induced symptoms in whole plants at 11 days post inoculation (dpi) (a) and on upper leaves (two leaves above the inoculated leaves) at 17 dpi (b). B, Symptoms induced by BYMV CS, BYMV 90-2, and mock inoculation on upper leaves (six leaves above the inoculated leaves) at 16 dpi. Experiments were repeated at least twice. Scale bar = $0.5 \mathrm{~cm}$. 
CIYVV-induced systemic cell death may be regulated by a resistance gene in PI 118501.

There have been many reports that viruses can systemically elicit cell death and kill plants (e.g., Soybean mosaic virus [SMV] infection in soybean, Spring beauty latent virus in A. thaliana, Cauliflower mosaic virus in N. clevelandii, and Tomato bushy stunt virus in $N$. benthamiana) (Fujisaki et al. 2004; Hajimorad et al. 2003; Király et al. 1999; Omarov et al. 2006). The SMV G7 strain systemically infects the soybean PI 96983 line and induces SCD and PRI expression (Hajimorad et al. 2003). SMV-induced SCD in PI 96983 is controlled by a single dominant gene, Rsv1. The Rsv1 allele of PI 96983 is tightly linked to a cluster of nucleotide binding site leucinerich repeat RGAs that include both toll interleukin 1 receptor (TIR) (single copy) and coiled-coil (large family of homologous sequences) types on linkage group (LG) F. Non-TIR type $3 \mathrm{gG} 2$ is a strong candidate for the major $R s v 1$ resistance gene (Hayes et al. 2004), suggesting that SMV-induced SCD is initiated from $R$-mediated recognition.

Ravero and associates (2007) indicated that ClYVV-induced SCD in pea PI 118501 is conferred by a single incompletely dominant locus, Cyn1. Although Cyn 1 is located in LG III (7.5 centimorgans from AD174, the nearest simple sequence repeat marker), synteny studies between pea and $M$. truncatula showed that the Cyn1-mapped region corresponds to the RGA cluster in M. truncatula LG III (Aubert et al. 2006; Zhu et al. 2002). We found that CIYVV induced SA-responsive and HR-related gene expression in cell-death-expressing tissue, suggesting that ClYVV-induced SCD is regulated by an $R$-gene-mediated pathway. However, although typical HR cell death and SA marker gene expression occurred within 3 days in tissue that was inoculated with virus particles (e.g., TMV-induced HR on N. tabacum and Turnip crinkle virus on A. thaliana), ClYVV-induced cell death was slower (5 to $6 \mathrm{dpi}$ ), as observed macroscopically; also, the SA-responsive PR gene was induced in inoculated leaves after 3 dpi (Fig. 2A) (Chandra-Shekara et al. 2004; Malamy et al. 1992). Dinesh-Kumar and associates (2000) demonstrated that TMV could spread from the infected area and induce cell death systemically in some tobacco mutant lines that have a partial loss-of-function mutation in the $N$ gene. This suggests that Cyn 1 is a naturally occurring weak resistance gene allele to ClYVV, or that ClYVV has weak elicitor molecules.

\section{RNA silencing suppression and cell death in PI 118501 (Cyn1).}

HCPro is a pathogenicity determinant in many susceptible plants (Atreya et al. 1992; Gal-On and Raccah 2000; Tribodet et al. 2005). For example, two amino acid substitutions in the C-terminal part of HCPro of Potato virus $Y$ abolish vein necrosis in N. tabacum cv. Xanthi (Tribodet et al. 2005). Yambao and associates (2008) found that a single amino acid substitution in ClYVV HCPro was sufficient to attenuate cell death induction in broad bean. In pea, CIYVV showed reduced ability to induce $\mathrm{SCD}$ via the introduction of mutations in the P1/HCPro region (Fig. 3B). We found that the order of virus accumulation was Cl-WT > Cl-CB > Cl-D193Y, showing a clear positive correlation with the extent of cell death. Because $\mathrm{P} 1 / \mathrm{HCPro}$ is an RSS, it is possible that RSS activity can explain the reduced virus accumulation or the cell death phenotype. Yambao and associates (2008) demonstrated that wildtype P1/HCPro could suppress strongly inverted-repeat-triggered RNA silencing in an A. tumefaciens-mediated transient assay in $N$. benthamiana. However, P1/HCPro-CB and -D193Y reduced RSS function, and the suppressor activity of P1/HCProCB was stronger than that of P1/HCPro-D193Y.

Kubota and associates (2003) showed that a mutant Tomato mosaic virus with a point mutation in RSS formed a ring-shaped
GFP lesion in GFP-transgenic N. tabacum that had undergone silencing of GFP mRNA. They found that the ring-shaped GFP fluorescence was caused by the failure to suppress the silencing of GFP in the center of the lesion (late phase of virus infection). This suggests that the ring-shaped GFP fluorescence pattern in Cl-CB and Cl-D193Y infection can be caused by decreased RNA silencing suppression. Moreover, we also observed that Cl-CB-derived GFP had both ring-shaped and non-ring-shaped fluorescence, depending on the cultivation conditions (light and temperature), supporting the idea that $\mathrm{Cl}$ $\mathrm{CB}$ is an intermediate loss-of-function mutant in RNA-silencing suppression (data not shown). These results show that CIYVV mutants had a reduced ability to induce cell death because of reduced RSS activity in pea, as is also observed in broad bean (Yambao et al. 2008). Furthermore, viral accumulation or the amount of elicitor may explain the weakened elicitation (Fig. 3D); there may be a threshold in the amount of elicitor molecules required for the induction of cell death.

Omarov and associates (2006) reported that Tomato bushy stunt virus P19 mutants attenuated lethal necrosis in $N$. benthamiana. They used two mutants; the P19/43 mutant had less viral siRNA-binding activity and the P19/75-78 mutant had no in vivo viral siRNA-binding activity. They showed that the siRNA-binding strength was positively correlated with systemic cell death induction. Two independent groups have reported that Tobacco etch virus HCPro can bind synthetic siRNA in vitro and can bind viral siRNA and endogenous miRNA in vivo, suggesting that small-RNA binding is a mechanism in RNA-silencing suppression by HCPro (Lakatos et al. 2006; Merai et al. 2006). It will be interesting to determine whether ClYVV P1/HCPro can bind siRNA, and if P1/HCPro mutants decrease the siRNA binding properties.

Taken together, it is likely that Cl-CB and Cl-D193Y accumulate fewer elicitor molecules than $\mathrm{Cl}$-WT because of reduced RSS activity, resulting in reduced activation of the SA signaling pathway and cell death. The application of BTH or SA supports elicitation by mutant viruses and can induce cell death in Cl-CB and Cl-D193Y infection (Fig. 5). Nevertheless, we cannot rule out the possibility that HCPro itself is an elicitor. Perhaps the decreased affinity of P1/HCPro-CB and -D193Y as elicitors to $C y n 1$ led to the weak activation of the SA signaling and HR-related pathways, and the application of BTH partially complemented the weak induction. To examine this, we are attempting to express each viral gene such as HCPro by $A$. tumefaciens infiltration in pea leaves to determine the elicitor molecules. Preliminary results have failed to show any GFP fluorescence in the infiltrated area with A. tumefaciens carrying a GFP construct, or even with A. tumefaciens KYRT1 strain, the best strain for producing transgenic pea plants (Grant et al. 2003).

We must also consider possible interconnections between P1/HCPro and the SA signaling pathway (Alamillo et al. 2006; Pruss et al. 2004). Pruss and associates (2004) reported that P1/HCPro transgenic tobacco plants confer enhanced resistance to multiple pathogens, including TMV, Tomato black ring nepovirus, and the oomycete Peronospora tabacina. P1/HCPro plants that carry the $N$ gene have smaller and fewer lesions after TMV infection than do control plants, conferred by both the SA-dependent and SA-independent pathways. In accordance with this result, Alamillo and associates (2006) reported that tobacco P1/HCPro transgenic plants altered SAmediated defense to Plum pox potyvirus. These phenotypes may be explained by P1/HCPro RNA-silencing activity, which interferes with endogenous silencing pathways such as the miRNA and siRNA pathways and include the pathogen-associated pathway (Kasschau et al. 2003; Katiyar-Agarwal 2006; Navarro et al. 2006). Furthermore, we must consider other 
functions of HCPro such as the interaction with $20 \mathrm{~S}$ proteasomes (Ballut et al. 2005).

\section{BTH specifically enhances CIYVV-induced symptoms in PI 226564 (cyn1).}

We found that BTH application enhanced symptom expression in both inoculated and upper leaves in PI 226564 (cyn1), similar to other non-SCD lines such as PI 250438, PI 347457 , and PI 331413. BTH could not enhance symptoms caused by BYMV CS, BYMV 90-2, and WCIMV, indicating that the enhancement of symptoms was specific to ClYVV in PI 226564. Enhanced viral virulence by BTH was contrary to many observed phenotypes in compatible interactions in which symptoms were attenuated (Singh et al. 2004). One explanation may be that PI 226564 has a weak Cyn 1 allele that is able to respond to ClYVV but not to BYMV and WCIMV, and that BTH supports the activation or the following Cyn1-regulated pathways because it could support the weakly activated Cyn1-regulated pathway in PI 118501 infected with CIYVV mutant viruses. We also tested the effect of exogenous SA application on symptom development but no symptom enhancement by SA was observed in PI 226564 infected with Cl-WT. The different effects of BTH and SA were also observed in wheat and cucumber (Görlach et al. 1996; Narusaka et al. 1999). In wheat, BTH strongly induces SA-responsive genes (WCl genes) and confers strong resistance against powdery mildew (Görlach et al. 1996). However, WCl gene expression and resistance induced by the exogenous application of SA appears weaker than that observed with the application of BTH. In pea, BTH stably and strongly activated the SA signaling pathway but SA did not (Supplementary Fig. S3). It is possible that the stable and strong activation of the SA signaling pathway enhances symptoms in PI 226564 that is infected with Cl-WT. To understand the molecular mechanism of ClYVVinduced systemic cell death in PI 118501 and enhancement of symptoms by BTH in PI 226564, it is clearly important to isolate the $C y n 1$ gene.

\section{MATERIALS AND METHODS}

\section{Plant growth conditions and viral infections.}

Pisum sativum (pea) and $N$. benthamiana were grown in a growth chamber at 21 to $23^{\circ} \mathrm{C}$ with a 16 -h photoperiod. Viral inocula were prepared as follows. First, infectious cDNA, ClWT, Cl-CB, and Cl-D193Y were inoculated onto broad bean (Vicia faba) by particle bombardment (Fig. 3) (Yambao et al. 2008). Upper leaves where GFP fluorescence was observed were used for inoculation (approximately 1 week later). Infected leaves were ground in inoculation buffer $(0.1 \mathrm{M}$ Tris- $\mathrm{HCl}, \mathrm{pH}$ 7.0, and 1\% 2-mercaptoethanol) and mechanical inoculation was performed as described previously (Sato et al. 2003). ClYVV was inoculated onto the third leaves of 2-week-old plants. At the same time, all plants were mock inoculated with inoculation buffer alone.

\section{Monitoring virus infection by GFP fluorescence.}

An epifluorescent microscope (SZX-12; Olympus, Tokyo) equipped with a filter cube (SZX-MGFPA; Olympus) was used to detect GFP. Images were recorded using a CCD camera (VB-6010; Keyence, Osaka, Japan).

\section{DAS-ELISA.}

A single GFP focus derived from virus was excised from inoculated leaves using a cork borer (4 $\mathrm{mm}$ in diameter). Each leaf disc (approximately $2 \mathrm{mg}$ ) was homogenized in $300 \mu \mathrm{l}$ of phosphate-buffered saline-Tween $20 \quad(0.01 \mathrm{M}$ phosphate buffer, $\mathrm{pH} 7.0$, and $0.05 \%$ Tween-20) and spun down, and the supernatants were used as antigens. DAS-ELISA was conducted using a mouse anti-ClYVV coat protein (CP) immunoglobulin $\mathrm{G}$ (IgG) as the first antibody and rabbit anti-CIYVV CP as the second antibody. After washing, alkaline phosphatase-conjugated goat anti-rabbit IgG was added, followed by the substrate solution ( $1 \mathrm{mg}$ of disodium $\rho$-nitrophenyl-phosphate hexahydrate in $1 \mathrm{ml}$ of $10 \%$ diethanolamine). The intensity of the signal was measured at an optical density (OD) of $405 \mathrm{~nm}$.

\section{Chemical treatment of plants.}

Inoculated leaves were soaked in a solution of $1 \mathrm{mM} \mathrm{BTH}$ (1.4\% acetone and $0.02 \%$ Tween-20) for $5 \mathrm{~s}$. Control plants were treated with water $(1.4 \%$ acetone and $0.02 \%$ Tween-20). Treatments were performed 1 to $4 \mathrm{dpi}$ at 24-h intervals. It is notable that the $300-$ and $500-\mu \mathrm{M}$ BTH treatments had similar effects in symptom enhancement (Fig. 7). Solutions of SA and 3-HBA were adjusted to $\mathrm{pH} 6.5$ with potassium hydroxide (Mayers et al. 2005). SA, 3-HBA, and control water contained $0.02 \%$ Tween-20. Inoculated plants were watered with $1 \mathrm{mM}$ SA, $1 \mathrm{mM} 3$-HBA, or control water for 6 days. We did not use a higher concentration of SA because it caused nonspecific deleterious effects on plants (data not shown).

\section{RNA extraction, RT, and real-time PCR.}

Leaves were homogenized in liquid nitrogen, and total RNA was isolated using TRIzol reagent (Invitrogen, Carlsbad, CA, U.S.A.) according to the manufacturer's instructions. Each RNA sample was treated with RNase-free DNase I (TaKaRa, Shiga, Japan), and 1 to $2 \mu \mathrm{g}$ of total RNA was reverse transcribed using cloned AMV RTase (Invitrogen). The RT reaction mixture $(20 \mu \mathrm{l})$ contained 1 to $2 \mu \mathrm{g}$ of total RNA, $2.5 \mu \mathrm{M}$ random 9-mers, $1 \mathrm{mM}$ dNTP, $5 \mathrm{mM}$ dithiothreitol, $40 \mathrm{U}$ of RNase Inhibitor (Wako, Osaka, Japan), cDNA synthesis buffer, and $15 \mathrm{U}$ of cloned AMV RTase. Samples were first incubated at $25^{\circ} \mathrm{C}$ for $10 \mathrm{~min}$, then at $45^{\circ} \mathrm{C}$ for $60 \mathrm{~min}$, and finally at $85^{\circ} \mathrm{C}$ for $5 \mathrm{~min}$.

Real-time PCR was performed using the DNA Engine Opticon 2 System (Bio-Rad, Hercules, CA, U.S.A.). The reaction mixture $(25 \mu \mathrm{l})$ contained $0.625 \mathrm{U}$ of ExTaq (TaKaRa), ExTaq buffer, $0.2 \mathrm{mM} \mathrm{dNTP}, 0.2 \mu \mathrm{M}$ forward and reverse primers, SYBRgreen $(\times 30,000$ dilution) (Invitrogen), and cDNA obtained by reverse transcribing 5 to $10 \mathrm{ng}$ of total RNA. Samples were incubated for $5 \mathrm{~min}$ at $95^{\circ} \mathrm{C}$; followed by 40 cycles of $95^{\circ} \mathrm{C}$ for $10 \mathrm{~s}, 53^{\circ} \mathrm{C}$ (for $S A-C H I$, accession number L37876, and $N$. benthamiana PRI [Kalde et al. 2007]) or $55^{\circ} \mathrm{C}$ (for SA-CHI2, no. X63899; JA-CHI, no. AB087832; and HSR203J, no. AB026296) for $30 \mathrm{~s}$, and $72^{\circ} \mathrm{C}$ for $20 \mathrm{~s}$. Transcript levels were normalized to that of $18 S$ rRNA (U43011 for pea and TC7411 [TIGR expressed sequence tag database] for $N$. benthamiana), and means and standard deviations were calculated. The primers used for real-time PCR were as follows: P. sativum: SA-CHI-F, 5'-CGGTTCAACCTCCGAATACT-3'; SA-CHI-R, 5'-TGTTGTTGAAGGTGTCACCG-3'; SA-CHI2F, 5'-CCAACACCGACAATACCAACAC-3'; SA-CHI2-R, 5'CACCAGTTGTACCAAATCCATT-3'; JA-CHI-F, 5'-GCAGA ACGCAACCCTTGCTTT-3'; JA-CHI-R, 5'-CCATTGTGTCG TTCTTGGTAGG3'; HSR203J-F, 5'-GTCCGGTTGGCTTAG AATCTAC-3'; HSR203J-R, 5'-GTAGTGCTCATGGTCACGT CACG-3'; 18SrRNA-F，5'-CGTTCTTAGTTGGTGGAGCGA T-3'; and 18SrRNA-R, 5'-CCATAGTCCCTCTAAGAAGCT G-3'; and $N$. benthamiana: PR1-F, 5'-TAGAACCTTTAACCT GGGACGA-3'; PR1-R, 5'-CTAAGTTTTCGCCGTATTGACC-3'; 18SrRNA-F, 5'-GCCCGTTGCTGCGATGATTC-3'; and 18SrRNA-R, 5'-GCTGCCTTCCTTGGATGTGG-3'.

\section{Trypan blue staining.}

Trypan blue staining was performed according to MoritaYamamuro and associates (2005). Leaves were vacuum-infil- 
trated with lactic acid-phenol-trypan blue solution (trypan blue at $2.5 \mathrm{mg} / \mathrm{ml}, 25 \%$ [wt/vol] lactic acid, 23\% Tris-EDTAsaturated phenol, $25 \%$ glycerol, and water) which was first heated to $70^{\circ} \mathrm{C}$. Leaves were then incubated in boiling water for $2 \mathrm{~min}$ and cooled for $1 \mathrm{~h}$. Finally, lactic acid-phenol-trypan blue solution was replaced with chloral hydrate solution $(25 \mathrm{~g}$ in $10 \mathrm{ml}$ of water) for destaining.

\section{ACKNOWLEDGMENTS}

We are grateful to S. Namba, C. Masuta, and D. Baulcombe for supplying WCIMV, CMV, and PVX, respectively. This study was supported in part by Grants-in-Aid for Scientific Research on Priority Areas (A) and Scientific Research (S) from the Ministry of Science, Education, Culture, and Technology of Japan.

\section{LITERATURE CITED}

Alamillo, J. M., Saénz, P., and García, J. A. 2006. Salicylic acid-mediated and RNA-silencing defense mechanisms cooperate in the restriction of systemic spread of Plum pox virus in tobacco. Plant J. 48:217-227.

Alvarez, M. E. 2000. Salicylic acid in the machinery of hypersensitive cell death and disease resistance. Plant Mol. Biol. 44:429-442.

Anandalakshmi, R., Pruss, G. J., Ge, X., Marathe, R., Mallory, A. C., Smith, T. H., and Vance, V. B. 1998. A viral suppressor of gene silencing in plants. Proc. Natl. Acad. Sci. U.S.A. 95:13079-13084.

Atreya, C. D., Atreya, P. L., Thornbury, D. W., and Pirone, T. P. 1992. Site-directed mutations in the potyvirus HC-Pro gene affect helper component activity, virus accumulation, and symptom expression in infected tobacco plants. Virology 191:106-111.

Aubert, G., Morin, J., Jacquin, F., Loridon, K., Quillet, M. C., Petit, A., Rameau, C., Lejeune-Hénaut, I., Huguet, T., and Burstin, J. 2006. Functional mapping in pea, as an aid to the candidate gene selection and for investigating synteny with the model legume Medicago truncatula. Theor. Appl. Genet. 112:1024-1041.

Ballut, L., Drucker, M., Pugnière, M., Cambon, F., Blanc, S., Roquet, F., Candresse, T., Schmid, H. P., Nicolas, P., Gall, O. L., and Badaoui, S. 2005. HcPro, a multifunctional protein encoded by a plant RNA virus, targets the $20 \mathrm{~S}$ proteasome and affects its enzymic activities. J. Gen. Virol. 86:2595-2603.

Brigneti, G., Voinnet, O., Li, W. X., Ji, L. H., Ding, S. W., and Baulcombe, D. C. 1998. Viral pathogenicity determinants are suppressors of transgene silencing in Nicotiana benthamiana. EMBO (Eur. Mol. Biol. Organ.) J. 17:6739-6746.

Chandra-Shekara, A. C., Navarre, D., Kachroo, A., Kang, H. G., Klessig, D., and Kachroo, P. 2004. Signaling requirements and role of salicylic acid in HRT- and rrt-mediated resistance to Turnip crinkle virus in Arabidopsis. Plant J. 40:647-659.

Chang, M. M., Horovitz, D., Culley, D., and Hadwiger, L. A. 1995. Molecular cloning and characterization of a pea chitinase gene expressed in response to wounding, fungal infection and the elicitor chitosan. Plant Mol. Biol. 28:105-111.

Chivasa, S., Murphy, A. M., Naylor, M., and Carr, J. P. 1997. Salicylic acid interferes with tobacco mosaic virus replication via a novel salicylhydroxamic acid-sensitive mechanism. Plant Cell 9:547-557.

Dinesh-Kumar, S. P., Tham, W. H., and Baker, B. J. 2000. Structurefunction analysis of the tobacco mosaic virus resistance gene N. Proc. Natl. Acad. Sci. U.S.A. 97:4789-14794.

Ding, S. W., and Voinnet, O. 2007. Antiviral immunity directed by small RNAs. Cell 130:413-426.

Durrant, W. E., and Dong, X. 2004. Systemic acquired resistance. Annu. Rev. Phytopathol. 42:185-209.

Friedrich, L., Lawton, K., Ruess, W., Masner, P., Specker, N., Rella, M. G., Meier, B., Dincher, S., Staub, T., Uknes, S., Métraux, J.-P., Kessmann, H., and Ryals, J. 1996. A benzothiadiazole derivative induces systemic acquired resistance in tobacco. Plant J. 10:61-70.

Fujisaki, K., Hagihara, F., Azukawa, Y., Kaido, M., Okuno, T., and Mise, K. 2004. Identification and characterization of the SSB1 locus involved in symptom development by Spring beauty latent virus infection in Arabidopsis thaliana. Mol. Plant-Microbe Interact. 17:967-975.

Gal-On, A., and Raccah, B. 2000. A point mutation in the FRNK motif of the potyvirus helper component-protease gene alters symptom expression in cucurbits and elicits protection against the severe homologous virus. Phytopathology 90:467-473.

Gilliland, A., Singh, D. P., Hayward, J. M., Moore, C. A., Murphy, A. M., York, C. J., Slator, J., and Carr, J. P. 2003. Genetic modification of alternative respiration has differential effects on antimycin A-induced versus salicylic acid-induced resistance to Tobacco mosaic virus. Plant Physiol. 132:1518-1528.

Görlach, J., Volrath, S., Knauf-Beiter, G., Hengy, G., Beckhove, U., Kogel, K. H., Oostendorp, M., Staub, T., Ward, E., Kessmann, H., and Ryals, J. 1996. Benzothiadiazole, a novel class of inducers of systemic acquired resistance, activates gene expression and disease resistance in wheat. Plant Cell 8:629-643.

Grant, J. E., Thomson, L. M., Pither-Joyce, M. D., Dale, T. M., and Cooper, P. A. 2003. Influence of Agrobacterium tumefaciens strain on the production of transgenic peas (Pisum sativum L.). Plant Cell Rep. 21:1207-1210.

Hajimorad, M. R., Eggenberger, A. L., and Hill, J. H. 2003. Evolution of Soybean mosaic virus-G7 molecularly cloned genome in Rsv1-genotype soybean results in emergence of a mutant capable of evading Rsv1mediated recognition. Virology 314:497-509.

Hayes, A. J., Jeong, S. C., Gore, M. A., Yu, Y. G., Buss, G. R., Tolin, S. A., and Maroof, M. A. 2004. Recombination within a nucleotide-binding-site/leucine-rich-repeat gene cluster produces new variants conditioning resistance to Soybean mosaic virus in soybeans. Genetics $166: 493-503$

Huang, Z., Yeakley, J. M., Garcia, E. W., Holdridge, J. D., Fan, J. B., and Whitham, S. A. 2005. Salicylic acid-dependent expression of host genes in compatible Arabidopsis-virus interactions. Plant Physiol. 137:1147-1159.

Ichinose, Y., Hisayasu, Y., Sanematsu, S., Ishiga, Y., Seki, H., Toyoda, K., Shiraishi, T., and Yamada, T. 2001. Molecular cloning and functional analysis of pea cDNA E86 encoding homologous protein to hypersensitivity-related hsr203J. Plant Sci. 160:997-1006.

Kalde, M., Nühse, T. S., Findlay, K., and Peck, S. C. 2007. The syntaxin SYP132 contributes to plant resistance against bacteria and secretion of pathogenesis-related protein 1. Proc. Natl. Acad. Sci. U.S.A. 104:11850-11855.

Kasschau, K. D., and Carrington, J. C. 1998. A counterdefensive strategy of plant viruses: Suppression of posttranscriptional gene silencing. Cell 95:461-470.

Kasschau, K. D., Xie, Z., Allen, E., Llave, C., Chapman, E. J., Krizan, K. A., and Carrington, J. C. 2003. P1/HC-Pro, a viral suppressor of RNA silencing, interferes with Arabidopsis development and miRNA function. Dev. Cell 4:205-217.

Katiyar-Agarwal, S., Morgan, R., Dahlbeck, D., Borsani, O., Villegas, A. Jr. , Zhu, J. K., Staskawicz, B. J., and Jin, H. 2006. A pathogen-inducible endogenous siRNA in plant immunity. Proc. Natl. Acad. Sci. U.S.A. 103:18002-18007.

Király, L., Cole, A. B., Bourque, J. E., and Schoelz, J. E. 1999. Systemic cell death is elicited by the interaction of a single gene in Nicotiana clevelandii and gene VI of Cauliflower mosaic virus. Mol. PlantMicrobe Interact. 12:919-925.

Kubota, K., Tsuda, S., Tamai, A., and Meshi, T. 2003. Tomato mosaic virus replication protein suppresses virus-targeted posttranscriptional gene silencing. J. Virol. 77:11016-11026.

Lakatos, L., Csorba, T., Pantaleo, V., Chapman, E. J., Carrington, J. C., Liu, Y. P., Dolja, V. V., Calvino, L. F., López-Moya, J. J., and Burgyán, J. 2006. Small RNA binding is a common strategy to suppress RNA silencing by several viral suppressors. EMBO (Eur. Mol. Biol. Organ.) J. 25:2768-2780.

Lecoq, H., Moury, B., Desbiez, C., Palloix, A., and Pitrat, M. 2004. Durable virus resistance in plants through conventional approaches: A challenge. Virus Res. 100:31-39.

Love, A. J., Yun, B. W., Laval, V., Loake, G. J., and Milner, J. J. 2005. Cauliflower mosaic virus, a compatible pathogen of Arabidopsis, engages three distinct defense-signaling pathways and activates rapid systemic generation of reactive oxygen species. Plant Physiol. 139:935-948.

Malamy, J., Hennig, J., and Klessig, D. F. 1992. Temperature-dependent induction of salicylic acid and its conjugates during the resistance response to Tobacco mosaic virus infection. Plant Cell 4:359-366.

Masuta, C., Yamana, T., Tacahashi, Y., Uyeda, I., Sato, M., Ueda, S., and Matsumura, T. 2000. Development of Clover yellow vein virus as an efficient, stable gene-expression system for legume species. Plant J. 23:539-546.

Mayers, C. N., Lee, K. C., Moore, C. A., Wong, S. M., and Carr, J. P. 2005. Salicylic acid-induced resistance to Cucumber mosaic virus in squash and Arabidopsis thaliana: Contrasting mechanisms of induction and antiviral action. Mol. Plant-Microbe Interact. 18:428-434.

Mérai, Z., Kerényi, Z., Kertész, S., Magna, M., Lakatos, L., and Silhavy, D. 2006. Double-stranded RNA binding may be a general plant RNA viral strategy to suppress RNA silencing. J. Virol. 80:5747-5756.

Morel, J. B., Godon, C., Mourrain, P., Béclin, C., Boutet, S., Feuerbach, F., Proux, F., and Vaucheret, H. 2002. Fertile hypomorphic ARGONAUTE (agol) mutants impaired in post-transcriptional gene silencing and virus resistance. Plant Cell 14:629-639. 
Morita-Yamamuro, C., Tsutsui, T., Sato, M., Yoshioka, H., Tamaoki, M. Ogawa, D., Matsuura, H., Yoshihara, T., Ikeda, A., Uyeda, I., and Yamaguchi, J. 2005. The Arabidopsis gene CAD1 controls programmed cell death in the plant immune system and encodes a protein containing a MACPF domain. Plant Cell Physiol. 46:902-912.

Nakamura, N., Marutani, M., Sanematsu, S., Toyoda, K., Inagaki, Y-S. Shiraishi, T., and Ichinose, Y. 2003. Phylogenetic classification of Doftype transcription factors in pea (Pisum sativum). Plant Biotechnol. 20:247-253.

Narusaka, Y., Narusaka, M., Horio, T., and Ishii, H. 1999. Comparison of local and systemic induction of acquired disease resistance in cucumber plants treated with benzothiadiazoles or salicylic acid. Plant Cell Physiol. 40:388-395

Navarro, L., Dunoyer, P., Jay, F., Arnold, B., Dharmasiri, N., Estelle, M., Voinnet, O., and Jones, J. 2006. A plant miRNA contributes to antibacterial resistance by repressing auxin signaling. Science 312:436439

Omarov, R., Sparks, K., Smith, L., Zindovic, J., and Scholthof, H. B. 2006. Biological relevance of a stable biochemical interaction between the tombusvirus-encoded P19 and short interfering RNAs. J. Virol. 80:3000-3008.

Pontier, D., Godiard, L., Marco, Y. and Roby, D. 1994. hsr203J, a tobacco gene whose activation is rapid, highly localized and specific for incompatible plant/pathogen interactions. Plant J. 5:507-521.

Pruss, G. J., Lawrence, C. B., Bass, T., Li, Q. Q., Bowman, L. H., and Vance, V. 2004. The potyviral suppressor of RNA silencing confers enhanced resistance to multiple pathogens. Virology 320:107-120.

Ravelo, G., Kagaya, U., Inukai, T., Sato, M., and Uyeda, I. 2007. Genetic analysis of lethal tip necrosis induced by Clover yellow vein virus infection in pea. J. Gen. Plant Pathol. 73:59-65

Sato, M., Masuta, C., and Uyeda, I. 2003. Natural resistance to Clover yellow vein virus in beans controlled by a single recessive locus. Mol. Plant-Microbe Interact. 16:994-1002.

Singh, D. P., Moore, C. A., GilliIand, A., and Carr, J. P. 2004. Activation of multiple antiviral defense mechanisms by salicylic acid. Mol. Plant Pathol. 5:57-63.

Soosaar, J. L., Burch-Smith, T. M., and Dinesh-Kumar, S. P. 2005. Mechanisms of plant resistance to viruses. Nat. Rev. Microbiol. 3:789-798.

Takahashi, Y., Takahashi, T., and Uyeda, I. 1997. A cDNA clone to Clover yellow vein potyvirus genome is highly infectious. Virus Genes $14: 235-243$.

Tribodet, M., Glais, L., Kerlan, C., and Jacquot, E. 2005. Characterization of Potato virus $Y$ (PVY) molecular determinants involved in the vein necrosis symptom induced by PVY $\mathrm{N}$ isolates in infected Nicotiana tabacum cv. Xanthi. J. Gen. Virol. 86:2101-2105.

Wang, Z. D., Ueda, S., Uyeda, I., Yagihashi, H., Sekiguchi, H., Tacahashi, Y., Sato, M., Ohya, K., Sugimoto, C., and Matsumura, T. 2003. Positional effect of gene insertion on genetic stability of a Clover yellow vein virus-based expression vector. J. Gen. Plant Pathol. 69:327-334.

Whitham, S. A., Yang, C., and Goodin, M. M. 2006. Global impact: Elucidating plant responses to viral infection. Mol. Plant-Microbe Interact. 19:1207-1215.

Xie, Z., Fan, B., Chen, C., and Chen, Z. 2001. An important role of an inducible RNA-dependent RNA polymerase in plant antiviral defense. Proc. Natl. Acad. Sci. U.S.A. 98:6516-6521.

Yambao, M. L., Yagihashi, H., Sekiguchi, H., Sekiguchi, T., Sasaki, T., Sato, M., Atsumi, G., Tacahashi, Y., Nakahara, K. S., and Uyeda, I. 2008. Point mutations in helper component protease of Clover yellow vein virus are associated with the attenuation of RNA-silencing suppression activity and symptom expression in broad bean. Arch. Virol. 153:105-115.

Zhang, X., Yuan, Y. R., Pei, Y., Lin, S. S., Tuschl, T., Patel, D. J., and Chua, N. H. 2006. Cucumber mosaic virus-encoded 2b suppressor inhibits Arabidopsis Argonaute1 cleavage activity to counter plant defense. Genes Dev. 20:3255-3268.

Zhu, H., Cannon, S. B., Young, N. D., and Cook, D. R. 2002. Phylogeny and genomic organization of the TIR and non-TIR NBS-LRR resistance gene family in Medicago truncatula. Mol. Plant-Microbe Interact. 15:529-539. 